\title{
IN VITRO DEVELOPMENTAL POTENTIAL OF BLASTOMERES SEPARATED FROM 4- AND 8-CELL RABBIT EMBRYOS AND CULTURED IN MEDIUM SUPPLEMENTED WITH AMINO ACIDS.
}

Shamiah, Sh. M.

Animal Production Research Institute, Agricultural Research center, Dokki, Giza, Egypt.

\begin{abstract}
This study aimed to compare the potential competence of blastomeres separated from intact 4-cell and 8-cell APRI rabbit embryos, and the effect of addition of essential (EAA) and non-essential (NEAA) amino acids on their in vitro developmental. Embryos were recovered from 16 APRI doe rabbits line superovulated by Equine Chorionic Gonadotropin (eCG), followed by $0.2 \mathrm{ml} \mathrm{GnRH}$ analogue immediately after natural mating with bucks of the same line. Embryos were collected 32-40 h post-coitum and only embryos at 4-cell and 8-cell stages were used in this study. Intact embryo or separated blastomeres were culture in vitro in TCM-199 unsupplemented (M1) or supplemented with $25 \mu \mathrm{l} / \mathrm{ml}$ (M2) or $50 \mu \mathrm{l} / \mathrm{ml}$ (M3) from each of EAA and NEAA. Results showed that separation rat of blastomeres was higher $(\mathrm{P}<0.05)$ from intact 4 -cell than 8 -cell embryos (95.3 vs. $81.7 \%)$. Cleavage (80.56 vs. $72.73 \%$ ) and morula/blastocyst production (65.74 vs. $58.18 \%$ ) rates were higher $(P \geq 0.05)$ of intact embryos at 4 -cell stage than those at 8-cell stage. Percentage of degenerated embryos showed an opposite trend. Cleavage (68.89 vs. $63.85 \%$ ) and morula/blastocyst production (47.11 vs. $44.06 \%$ ) rates were higher of blastomeres of 4-cell than 8-cell embryos. Percentage of degenerated embryos showed an opposite trend. M3 improved the cleavage of blastomeres of 4-cell embryos (76.92 vs. $61.33 \%$, $\mathrm{P}<0.05)$ and those of 8 -cell embryos $(67.46$ vs. $56.69 \%, \mathrm{P} \geq 0.5)$ as compared to $\mathrm{M} 1$, meanwhile M2 insignificantly improved cleavage rate of blastomeres of 4-cell or 8-cell embryos. Also, M3 improved $(\mathrm{P}<0.05)$ morula/blastocyst production rate of blastomeres of 4-cell or 8-cell embryos as compared to M1 and M2. Percentage of degenerated embryos was insignificantly improved by amino acid addition (M2 and M3) as compared to M1.

In conclusion, potential competence of blastomeres to morula/blastocysts was better when blastomeres were separated from intact embryos at 4-cell than at 8cell stage. This potential competence of blastomeres of 4-cell or 8-cell embryos to morula/blastocyst stage improved when in vitro culture medium (TCM-199) was supplemented with essential and non-essential amino acids at a level of $50 \mu \mathrm{l} / \mathrm{ml}$ from each.
\end{abstract}

Keywords: Rabbit, intact embryo, blastomeres, morula/blastocysts, amino acids

\section{INTRODUCTION}

The reproductive characteristics of the rabbit, including easily controlled ovulation time, make it a good model for the timed study of embryology developmental biology, cloning and genetic engineering. Artificial animal cloning by separated blastomere technique from embryonic cells has been applied to various animals including mammals, mice, rabbits, sheep and pigs (Willadsen, 1979). The developmental capacity of separated blastomeres from mammalian embryos has been studied extensively, and has proved of great value in the investigation of cellular and regulatory aspects of development in animals e.g. rabbit (Moore et al., 1968), sheep 
(Willadsen, 1982), cattle (Eckert et al., 1997) and human for pre-implantation genetic diagnosis (Viville et al., 1998), for assessing the developmental potential of the parent embryos (Gaber and Sampaio, 1999) or to gain insight into regulatory mechanisms in pre-implantation development (Krussel et al., 1998) and sex determination (Taskin et al., 2011).

The developmental competence of early embryonic blastomeres (BTMs) is one of the fundamental questions in developmental biology that has not been fully elucidated (Piotrowska-Nitsche and Zernicka-Goetz, 2005; Piotrowska-Nitsche et al., 2005). Unfortunately, not all early BTMs are able to develop to term (Mitalipov et al., 2002). Contrary, 2-, 4-, and 8-cell sheep embryos show no difference in producing monozygotic twins (Willadsen, 1979). Although monozygotic twins have been produced by separating 2-cell embryos in some species (Matsumoto et al., 1989), there was a report showing the pluripotency of 4- cell BTMs that produced quadruplets, four identical calves (Johnson et al., 1995).

It has been shown that blastomeres separated from embryos at different stages (2-cell mouse, 4-8-cell rabbit, 4-cell bovine, and 8-cell ovine and porcine) are capable of regular in vitro development upon transfer to suitable recipients (Saito and Niemann, 1991). Also, blastomeres of a 4-cell mouse embryos can develop into a blastocysts and implant (Tarkowski et al., 2001). Moreover, some separated cells of an 8-cell mouse embryos form only small trophoblasts (Edwards and Beard, 1997). Both blastomeres of 2-cell ovine embryos can develop into lambs (Willadsen and Godke, 1984), and all the cells of 4-cell bovine embryo are totipotent (Johnson et al., 1995).

Amino acids serve a variety of physiological function, including; synthesis of proteins and nucleolotides (Katchadourian et al, 1994) nutrition and energy provision (Houghton et al, 2002), osmo-regulation (Dawson et al,1998), protection against oxidative stress (Nasr-Esfahani et al. 1992), $\mathrm{pH}$ regulation (Edwared et al, 1998) signaling molecule biosynthesis (Wu and Morris 1998), trophectoderm differentiation (Martin and Sutherland, 2001) and basement membrane formation between primitive endoderm and ectoderm (Biggers et al., 2000). Therefore, in vitro development of separated blastomeres is limited by suboptimal culture system (Willadsen, 1991; Menino and Wright, 1991). Several investigations including supplementation of the medium with lamb serum (Saito and Niemman, 1991) or coating the culture dishes with fibronectin (Wilton and Trounson, 1999). Furthermore, there are given effects of essential and non-essential amino acids on embryonic physiology, and blastocyst development in many species (Rieger et al., 1992; Swain et al., 2002). Development of the early cleavage stages was stimulated by the non-essential amino acids and glutamine while development beyond 3 days was stimulated by a combination of the non- essential and essential amino acids and glutamine in buffalo (Badr, 2009).

Therefore, the purpose of this study was to compare the potential competence of blastomeres separated from intact 4-cell and 8-cell APRI rabbit embryos, and the effect of addition of essential and non-essential amino acids on their in vitro developmental. 


\section{MATERIALS AND METHODS}

Animals:

A total of $16 \mathrm{APRI}$ strains rabbit does, of approximately 5-7 months of age, 3-3.5 kg live body weight (LBW) and within $1^{\text {st }}-2^{\text {nd }}$ parity were used in this study as donors of embryos. In addition, 3 fertile APRI bucks, around 8 months of age and averaged $3.75 \mathrm{~kg}$ LBW were used for natural mating.

All does and bucks were kept under the same conditions of feeding and management in Sakha Animals Production Research Station. All animals were individually housed in metal cages $(40 \times 50 \times 60 \mathrm{~cm})$ provided with feeders and water nibble in each cage. Does and bucks were fed ad libitum on a commercial pelleted diet.

Embryo recovery:

Rabbit does were $(n=16)$ were superovulated by intramuscular injection of $40 \mathrm{lU} / \mathrm{kg}$ live body weight from Equine Chorionic Gonadotropin (eCG) (Folligon, Intervet International B.V., Boxmeer, Netherlands), followed by $0.2 \mathrm{ml} \mathrm{GnRH}$ analogue (Receptal, Intervet International B.V., Boxmeer, Holland) immediately after natural mating.

Embryos were recovered by flushing from doe according to the developmental stage of embryo ( $n=8$ does / stage), 4 and 8 -cell embryos stages were collected $32 \mathrm{~h}$ and $40 \mathrm{~h}$ post- GnRH injected, respectively.

Phosphate buffer saline (PBS) medium was prepared according to Gordon (1994), supplemented with $2 \mathrm{mg} / \mathrm{ml}$ Bovine Serum Albumin (BSA), 22 $\mathrm{mMol} \mathrm{Na}$ - pyruvate (final concentration) and $50 \mu \mathrm{g} / \mathrm{ml}$ Gentamycin sulphate.

All media was adjusted to $\mathrm{pH}$ value of 7.2-7.4 using $\mathrm{pH}$-meter and to osmolarity level of $280-300 \mathrm{mOsmol} / \mathrm{kg}$ using osmometer. Then, the medium was filtered by $0.22 \mu \mathrm{m}$ millipore filter (milieux GV, millepore, Cooperation Bedford MOA).

Embryos were recovered from each oviduct per doe by flushing using PBS. The flushings were collected in sterile plastic Petri dishes and embryos were washed three times with PBS, counted and evaluated for viable and unviable embryos under a stereomicroscope at a magnification of 20-40 x. Viable embryos were used in this study.

All chemicals used in this study were purchased from Sigma (Madrid, Spain), unless otherwise indicated.

\section{Blastomere separation:}

Immediately after embryo recovery, viable embryos were put in acidified phosphate-buffered saline (PBS; pH 2.5) until zona pellucida was dissolved, after that they were transferred to $0.25 \%$ trypsin (Cat. No. 25050; Invitrogen) at a level of 1:250 dilution until the mucin coat (where it was present) disappeared. Individual blastomeres were separated by repeated pipetting gently the zona pellucida free embryo in PBS plus $5 \%$ BSA with a $50 \mu \mathrm{m}$ fire polished pipette, according to (Cervera and Garcia-XimeÂnez, 2003)

Embryo culture:

Intact embryos at 4-cell and 8-cell stages or their separated blastomeres were cultured in vitro by placing into 4-well Petri dishes 
containing (0.5 ml per well) basic medium (TCM-199, The Egyptian Organization for Biological Products and Vaccine- Agouza, Egypt) supplemented with $22 \mathrm{mMol} \mathrm{Na}$ - pyruvate (final concentration), $4 \mathrm{mg} / \mathrm{ml} \mathrm{BSA}$ and $50 \mu \mathrm{g} / \mathrm{ml}$ gentamycin sulphate as control medium (M1). The basic medium was supplemented with solution of essential (EAA, 50x) and nonessential amino acids (NEAA,100x) at a level of $25 \mu \mathrm{l} / \mathrm{ml}$ from each (M2, low level of EEAA+NEAA) or at a level of $50 \mu \mathrm{l} / \mathrm{ml}$ from each of EAA and NEAA (M3, high level of EEAA+NEAA). Media were covered with sterile mineral oil and incubated at $38.5^{\circ} \mathrm{C}$ and $5 \% \mathrm{CO}_{2}$ with $95 \%$ humidity for intact embryos at 4-cell and 8-cell stages and their blastomeres for 96 and $72 \mathrm{~h}$, respectively. Each medium was replacement every $24 \mathrm{~h}$ with the same medium.

Embryos were examined by inverted microscope (x200 magnification) for development to morula/blastocyst stage as well as degenerated embryos.

Statistical analysis:

The experiment was replicated 4 times for both development, morula/blastocyst production rate and degenerated embryos. Data were statistically analyzed by analysis of variance (ANOVA, one way) using SAS (2004) after arcsine transformation. Dunacn's Multiple Range Test was followed for test the significant differences among means (Duncan, 1955).

\section{RESULTS AND DISCUSSION}

\section{Blastomere separation rates:}

Results presented in Table (1) revealed that a total of 225 and 379 blastomeres were separated from 59 and 58 embryos at 4-cell and 8-cell stages, respectively, representing significantly $(P<0.05)$ higher blastomere separation rate from 4-cell than 8-cell embryos (95.3 vs. 81.7\%).

Table (1): Embryo recovery and blastomere separation rates of superovulated rabbit does.

\begin{tabular}{|l|c|c|c|}
\hline \multicolumn{1}{|c|}{ Item } & Total & 4-cell embryos & 8-cell embryos \\
\hline Number of rabbit donors & 16 & - & - \\
\hline Recovered embryos & 370 & - & - \\
\hline Number of embryos/donor & 23.1 & - & - \\
\hline Number of viable embryo /donor & 20.94 & - & - \\
\hline Intact embryos & 218 & 108 & 58 \\
\hline Number of separated embryos & 117 & 59 & 379 \\
\hline Number of blastomeres & 604 & 225 & $81.7^{\text {b }}$ \\
\hline Blastomere separation rate (\%) & - & $95.3^{\text {a }}$ & sificantly \\
\hline
\end{tabular}

$a$ and $b$ : Means denoted within the same row with different superscripts are significantly different at $\mathrm{P}<0.05$.

\section{In vitro developmental competence:}

In comparison of development rate and morula/blastocyst production rate between intact embryos at 4-cell and 8-cell stages, results shown in Table (2) revealed higher cleavage rate (80.56 vs. $72.73 \%)$ and in vitro developmental competence in term of morula/blastocyst production rate (65.74 vs. 58.18\%) of intact embryos at 4-cell than at 8-cell stage, but the differences were not significant. However, percentage of degenerated embryos showed an opposite trend. 
On the other side, also cleavage rate (68.89 vs. 63.85\%) and morula/blastocyst production rate $(47.11$ vs. $44.06 \%)$ were higher of blastomeres separated from embryos at 4-cell than 8-cell stages, and percentage of degenerated embryos showed an opposite trend, but the differences were not significant (Table 2).

Moreover, these results (Table 2) showed significant $(P<0.05)$ differences in development rate, morula/blastocyst production rate and percentage of degenerated embryos only between intact 4-cell embryos and those of blastomeres separated from 8-cell embryos, being better in intact 4cell embryos than in blastomeres of 8-cell embryos.

Such results indicated that separated blastomeres from intact 4-cell embryos had favorably higher cleavage and morula/blastocyst production rates as compared those separated from intact 8-cell embryos. However, cleavage and morula/blastocyst production rates were higher for intact embryos at 4-cell or 8-cell stages than their separated blastomeres (Table 2 and Plate 1).

Table (2): In vitro developmental competence of intact 4-cell and 8-cell embryos or their separated blastomeres.

\begin{tabular}{|c|c|c|c|c|c|c|c|}
\hline \multirow{2}{*}{$\begin{array}{c}\text { Embryonic } \\
\text { stage }\end{array}$} & \multirow{2}{*}{ Total } & \multicolumn{2}{c|}{ Development $^{*}$} & \multicolumn{2}{c|}{$\begin{array}{c}\text { Morula/ } \\
\text { Blastocyst }\end{array}$} & \multicolumn{2}{c|}{ Degenerated } \\
\cline { 3 - 8 } & & $\mathbf{n}$ & $\%$ & $\mathbf{n}$ & $\%$ & $\mathbf{n}$ & $\%$ \\
\hline Intact 4-cell embryos & 108 & 87 & $80.56^{\mathrm{a}}$ & 71 & $65.74^{\mathrm{a}}$ & 10 & $9.26^{\mathrm{b}}$ \\
\hline Intact 8-cell embryos & 110 & 80 & $72.73^{\mathrm{ab}}$ & 64 & $58.18^{\mathrm{a}}$ & 19 & $17.27^{\mathrm{ab}}$ \\
\hline BTMs of 4-cell embryos & 225 & 155 & $68.89^{\mathrm{b}}$ & 106 & $47.11^{\mathrm{b}}$ & 32 & $14.22^{\mathrm{ab}}$ \\
\hline BTMs of 8-cell embryos & 379 & 242 & $63.85^{\mathrm{b}}$ & 167 & $44.06^{\mathrm{b}}$ & 75 & $19.79^{\mathrm{a}}$ \\
\hline
\end{tabular}

$a$ and $b$ : Means denoted within the same row with different superscripts are significantly different at $P<0.05$.

BTMs: Blastomeres. *Development to the next embryonic stages.

In accordance with the present results, Tao and Niemann (2000) reported that cell division of separated blastomeres deceased with increasing stages of the parent embryos reflecting a cell size-dependent control of the cell division such that larger blastomeres from 4-cell embryos divide sooner than smaller blastomeres 8-cell and 16-cell embryos in rabbit.

The timing of human embryonic genome activation between the 4and 8-cell stages (Braude et al., 1988) explains the flexibility of the cells at the 4-cell stage. Van de Velde et al. (2008) postulate that the blastomeres of a 4-cell stage human embryo are flexible and able to develop into blastocysts with inner cell mass (ICM) and trophectoderm (TE).

Mitalipov et al. (2002) reported that not all BTMs were able to develop to term. On the contrary, 2-, 4-, and 8-cell sheep embryos show no difference in producing monozygotic twins (Willadsen, 1979). Although monozygotic twins have been produced by separating two-cell embryos in some species (Allen and Pashen, 1984; Matsumoto et al., 1989), there was only one report showing the pluripotency of four cell BTMs that produced quadruplets (four identical calves) (Johnson et al., 1995).

A blastomere of a 4-cell stage mouse embryo can develop into a blastocyst and implant, but will die soon because of its small size and the 
insufficient cell number of its inner cell mass (ICM). Indirect evidence that at least some of the blastomeres of a 4-cell stage mouse embryo are totipotent was provided in chimeric models using carrier blastomeres of a different genotype to keep the size and cell number of the embryos normal (Tarkowski et al., 2001).

Some separated cells of an 8-cell stage mouse embryo form only small trophoblasts (Edwards and Beard, 1997). Both blastomeres of 2-cell stage ovine embryos can develop into lambs (Willadsen and Godke, 1984), and all the cells of a 4-cell stage bovine embryo are totipotent (Johnson et al., 1995).

The embryonic genome becomes activated earlier in the mouse (Flach et al., 1982; Bolton et al., 1984), which could explain the differences between the species.

It has been shown that separated blastomeres from 2-cell mouse, 48-cell rabbit, 4-cell bovine as well as 8-cell ovine and porcine embryos are capable of regular in-vitro development upon transfer to suitable recipients (Saito and Niemann, 1991).

In addition, a blastomere of a 4-cell stage mouse embryo can develop into a morula/blastocyst and implant, but will die soon because of its small size and the insufficient cell number of its inner cell mass (ICM). Indirect evidence that at least some of the blastomeres of a 4-cell stage mouse embryo are totipotent was provided in chimeric models using carrier blastomeres of a different genotype to keep the size and cell number of the embryos normal (Tarkowski et al., 2001). Moreover, some separated cells of an 8-cell stage mouse embryo form only small trophoblasts (Edwards and Beard, 1997). Both blastomeres of 2-cell stage ovine embryos can develop into lambs (Willadsen and Godke, 1984), and all the cells of a 4-cell stage bovine embryo are totipotent (Johnson et al., 1995).
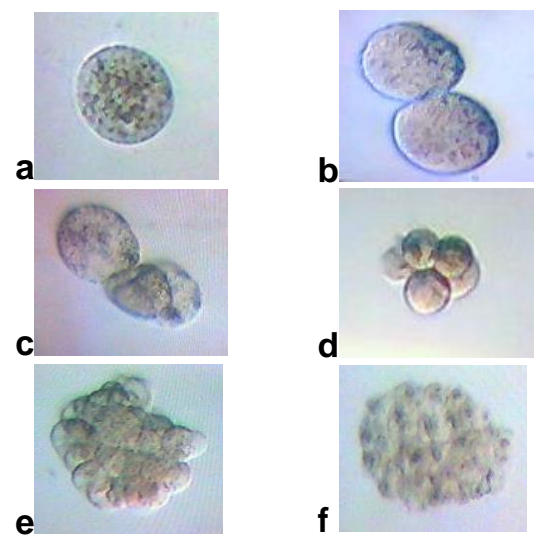

\author{
Plate (1): \\ Development of blastomere \\ separated from intact rabbit \\ embryos(a) to embryo at \\ 2-cell (b), 4-cell (c), 8-cell (d), \\ morula (e) and blastocyst (f) \\ stages.
}

\title{
Effect of amino acid addition to in vitro culture medium:
}

Data in Tables 3 show that amino acid addition to in vitro culture medium had significant $(P<0.05)$ effect on cleavage and morula/blastocyst production rates of blastomeres separated from intact embryos (4-cell and 8- 
cell). Using M3 improved the cleavage rate of blastomeres significantly $\mathrm{P}<0.05)$ for those separated from 4-cell embryos $(76.92$ vs. $61.33 \%)$ and insignificantly for those separated from 8-cell embryos (67.46 vs. $56.69 \%)$ as compared to $M 1$, meanwhile $M 2$ insignificantly improved cleavage rate of blastomeres of 4 -cell or 8 -cell embryos. Also, M3 significantly $(P<0.05)$ improved morula/blastocyst production rate of blastomeres separated from intact 4-cell or 8-cell embryos as compared to M1 and M2. On the other hand, percentage of degenerated embryos was insignificantly improved by amino acid addition (M2 and M3) as compared to M1.

Table (3): Effect of amino acid supplementation to culture medium on in vitro developmental competence of blastomeres derived from 4 and 8-cell stages.

\begin{tabular}{|c|c|c|c|c|c|c|c|c|}
\hline \multirow{2}{*}{$\begin{array}{c}\text { Embryonic } \\
\text { stage }\end{array}$} & \multirow{2}{*}{$\begin{array}{c}\text { Culture } \\
\text { medium }\end{array}$} & \multirow{2}{*}{$\begin{array}{c}\text { Total } \\
\text { BTMs }\end{array}$} & \multicolumn{2}{|c|}{ Cleavage } & \multicolumn{2}{c|}{ Morula/Blastocyst } & \multicolumn{2}{c|}{ Degenerated } \\
\cline { 5 - 9 } & M1 & 75 & 46 & $61.33^{\mathrm{b}}$ & $\mathbf{n}$ & $\%$ & $\mathbf{n}$ & $\%$ \\
\hline \multirow{2}{*}{ BTMs of } & M2 & 72 & 49 & $68.06^{\mathrm{ab}}$ & 33 & $41.33^{\mathrm{bc}}$ & 11 & 14.67 \\
4-cell embryos & M3 & 78 & 60 & $76.92^{\mathrm{a}}$ & 42 & $53.83^{\mathrm{abc}}$ & 11 & 15.28 \\
& M1 & 129 & 77 & $59.69^{\mathrm{b}}$ & 49 & $37.98^{\mathrm{c}}$ & 28 & 21.71 \\
& M2 & 124 & 80 & $64.52^{\mathrm{b}}$ & 54 & $43.55^{\mathrm{bc}}$ & 24 & 19.35 \\
BTMs of & M3 & 126 & 85 & $67.46^{\mathrm{ab}}$ & 64 & $50.79^{\mathrm{ab}}$ & 23 & 18.25 \\
\hline
\end{tabular}

a, b and c: Means denoted within the same column with different superscripts are significantly different at $P<0.05$.

M1: Unsupplemented medium. M2: Medium with $25 \mu \mathrm{l}$ EAA+25 $\mu$ l NEAA/ml. M3: Medium with $50 \mu \mathrm{l}$ EAA+50 $\mu \mathrm{l}$ NEAA/ml. BTMs: Blastomeres.

It is of interest to note that addition of amino acids at high level to in vitro culture media (M3) showed slightly higher improvement of blastomeres of 8-cell than that of 4-cell embryos to reach morula/blastocy stage (30.3 vs. $33.7 \%)$

The nutrient requirements change upon embryonic genomic activation which has led to the development of sequential media that better mimic the physiological condition in the uterine cavity and improve embryo development and viability (Gardner and Lane, 1996; Gardner, 1994). In agreement with the present results, Badr (2009) found that development of the early cleavage stages was stimulated by the non- essential amino acids and glutamine while development beyond 3 days was stimulated by a combination of EAA, NEAA and glutamine. In this respect, Huang et al. (2004) reported that amino acids had certain specific functions in the development of pig embryos to the morula/blastocyst stage. Addition of NEAA and glutamine stimulated cleavage, differentiation of cells to ICM and fetal development after transfer. Also, Kane (1987) observed that presence of vitamins and amino acids had previously been shown to be an essential requirement for rabbit embryo development.

Amino acids serve a variety of physiological function, including; synthesis of proteins and nucleolotides (Katchadourian et al, 1994) nutrition and energy provision (Houghton et al, 2002), osmo-regulation (Dawson et al,1998), protection against oxidative stress (Nasr-Esfahani et al. 1992), $\mathrm{pH}$ regulation (Edwared et al, 1998) signaling molecule biosynthesis (Wu and Morris 1998), trophectoderm differentiation (Martin and Sutherland, 2001) 
and basement membrane formation between primitive endoderm and ectoderm (Biggers et al., 2000).

In the samer respect, there are given effects of essential and nonessential amino acids on embryonic physiology, and morula/blastocyst development was improved in many species by culture in relatively simple media containing optimized concentrations of amino acids (Rieger et al., 1992; Swain et al., 2002). In buffalo, Badr (2009) found that development of the early cleavage stages was stimulated by the non-essential amino acids and glutamine while development beyond 3 days was stimulated by a combination of the non- essential and essential amino acids and glutamine.

In conclusion, potential competence of blastomeres to morula/blastocysts was better when blastomeres were separated from intact embryos at 4-cell than at 8-cell stage. This potential competence of blastomeres of 4-cell or 8-cell embryos to morula/blastocyst stage improved when in vitro culture medium (TCM-199) was supplemented with $50 \mu \mathrm{l}$ from each of essential and non-essential amino acids.

\section{REFERENCES}

Nasr-Esfahani, M.H.; Winston, N.J. and Johnson, M.H. (1992). Effect of glucose glutamine, ethylenediaminetetraacetic acid and oxygen tension on the concentration of reactive oxygen species and on the development of the mouse preimplantation in vitro. Journal of Reproductive and Fertility, 96: 219-231.

Allen, W.R. and Pashen, R.L. (1984). Production of monozygotic (identical) horse twins by embryo micromanipulation. Journal of Reproductive and Fertility, 71:607-613.

Badr, M.R. (2009). Effects of supplementation with amino acids on in vitro buffalo embryo development in defined cultured media. Global Veterinaria, 3 (5): 407-413.

Biggers, J.D.; McGinnis, L. and Raffin, M. (2000). Amino acids and preimplantation development of the mouse in protein-free potassium simplex optimized medium. Biology of Reproduction, 63: 281-293.

Bolton, V.N.; Oades, P.J. and Johnson, M.H. (1984). The relationship between cleavage, DNA replication and gene expression in the mouse 2-cell embryo. Journal of Embryology and Experimental Morphology, 79:139-163.

Braude, P.; Bolton V. and Moore, S. (1988). Human gene expression first occurs between the four-and eight-cell stages of preimplantation development. Nature, 332:459-461.

Cervera and Garcia-XimeÂnez (2003). Vitrication of zona-free rabbit expanded or hatching blastocysts: a possible model for human blastocysts. Human Reproduction Vol.18, No.10 pp. 2151 \pm 2156.

Dawson, K.M. Collins J.L. and Baltz, J.M. (1998). Osmolarity-dependent glycine accumulation indicates a role for glycine as an organic osmolyte in early preimplantation mouse embryos. Biology of Reproduction, 59: 225-22.

Duncan, D. B., (1955). Multiple range and multiple F. Test biometrics.; 11: 142. 
Eckert, J., Tao, T. and Niemann. H. (1997). Ratio of inner cell mass and trophoplastic cell in blastocysts derived from porcine 4- and 8-cell embryo isolated blastomeres culture in vitro in the presence or absence of protein and human leukemia inhibitory factors. Biol. Reprod, 57: 557560.

Edwards, R.G. and Beard, H.K. (1997). Oocyte polarity and cell determination in early mammalian embryos. Mol. Hum. Reprod., 3: 863-905.

Edwared, L.J.; Williams D.A. and Gardner, D.K. (1998). Intracellular pH of the mouse preimplantation embryo: amino acid act as buffers of intracellular pH. Human Reproduction, 13: 3441-3448.

Flach, G.; Johnson, M.H. Braude, P.R. Taylor, R.A. and Bolton, V.N. (1982). The transition from maternal to embryonic control in the 2-cell mouse embryo. EMBO Journal, 1: 681-686.

Gaber, S. and Sampaio, M. (1999). Blastomeres development after embryo biopsy: a new model to predict embryo development and to select for transfer. Hum. Reprod., 14: 782-786.

Gardner, D.K. (1994). Culture of mammalian embryos in the absence of serum and somatic cells. Cell. Biol. Int., 18: 1163-1179.

Gardner, D.M. and Lane, M. (1996). Alleviation of the '2-cell block' and development to the blastocyst of CF1 mouse embryos: role of amino acids, EDTA and physical factors. Hum. Reprod., 11: 2703-2712.

Gordon, L. (1994). Laboratory production of cattle embryos CAB International Wallingfored. UK.

Huang, Y.J.; Presicce, G.A.; Gasparrini, B. Yang, B.Z. Liang, X.W. Zhang, X.F. Chen, M.T. Li, Z.Q. and Huang, F.X. (2004). Researches on ovum pick-up and in vitro fertilization in buffalo. China Anim. Husband. Vet. Med., 11-22.

Johnson, W.H.; Loskutoff, N.M.; Plante, Y. and Betteridge, K.J. (1995). Production of four identical calves by the separation of blastomeres from an in vitro derived four-cell embryo. Veterinary Record., 137: 1516.

Kane, M.T. (1987). In vitro growth of perimplantation rabbit embryos. In Bavister, B.D, (ed) The mammalian preimplantation embryo. Plenum Press New York USA, pp. 193-217.

Katchadourian C. Joly C. and Menezo Y. (1994). Interactions in glycine and methonine uptake, conversion and incorporation into proteins in the preimplantation mouse embryo. Zygote, 2: 301-306.

Krussel, J.S. Simon, C. Rubio, M.C. et al (1998). Expression of intrerleukinl system mRNA in single blastomeres from human preimplantation embryos. Hum. Reprod., 13: 2206-2211.

Martin, P.M and Sutherland A.E. (2001). Exogenous amino acids regular trophectoderm differentiation in the mouse blastocyst through an mTOR- dependent pathway. Developmental Biology, 240: 182-193.

Matsumoto, K. Miyake, M. Utsumi, K. and Iritani, A. (1989). Production of identical twins by separating two-cell rat embryos. Gamete Research, 22: 257-263. 
Menino, A.R. and Wright, R.W. (1991). Effect of pronase treatment, micro dissection and zona pellucida on the development of porcine embryos and blastomeres. Biol. reprod.; 44: 927-36.

Mitalipov, S.M.; Yeoman, R.R.; Kuo, H.C. and Wolf, D.P. (2002). Monozygotic twinning in rhesus monkeys by manipulation of in vitro-derived embryos. Biology of Reproduction, 66: 1449-1455.

Moore, N.M. Adams, C.E. and Rowsan, L.E.A. (1968). Developmental potential of single blastomeres of the rabbit egg. Journal of Reproductive and Fertility, 17: 527-31.

Piotrowska-Nitsche, K. and Zernicka-Goetz, M. (2005). Spatial arrangement of individual 4-cell stage blastomeres and the order in which they are generated correlate with blastocyst pattern in the mouse embryo. Mechanism of Development, 122: 487-500.

Piotrowska-Nitsche, K. Perea-Gomez, A. Haraguchi, S. and Zernicka-Goetz, M. (2005). Four-cell stage mouse blastomeres have different developmental properties. Development, 132: 479-490.

Rieger, D.; Loskutoff, N.M. and Betterridge, K.J. (1992). Developmentally related changes in the metabolism of glucose and glutamine by cattle embryos produced and co-cultured in vitro. Journal of Reproductive and Fertility, 95: 585-595

Saito, S. and Niemman, H. (1991). Effect of extra cellular matrices and growth factor on the development of isolated porcine blastomeres. Biol. Reprod.; 44: 927-36.

Statistical Analysis Systems (SAS). SAS User's Guide. Cary, NC: Statistical Analysis Systems Institute Inc; 2004

Swain, J. E.; Bor Mann, C. L.; Clark, S. G.; Walters, E. M.; wheeler, M. B. and kisher, R. L.(2002). Use of energy substrates by various stage preimplantation pig embryos produced in vivo and in vitro. Reprod.,123: 253-260.

Tao, T. and Niemann. H. (2000). Cellular characterization of blastocysts derived from rabbit 4,8 and 16 cell embyos and isolated blastomeres cultured in vitro. Human Reproduction, vol. 15: 881-889.

Tarkowski, A.K.; Ozdzenski, W. and Czolowska, R. (2001). How many blastomeres of the 4 cell embryo contribute cells to the mouse body? Int. J. Dev. Biol.; 45: 811-816.

Taskin, A.G.; Akkoc, T. Caputcu, A.T. Arat, S. and Bagis, H. (2011). Optimal method of mouse blastomere biopsy: in vitro developmental potential of the biopsied embryo to blastocyst stage after aspirated eight-cell mouse embryos. Journal of Animal and Veterinary Advances, 10 (22): 3027-3030.

Van de Velde, H. Cauffman, G. Tournaye, H. Devroey, P. and Liebaers, I. (2008). The four blastomeres of a 4-cell stage human embryo are able to develop individually into blastocysts with inner cell mass and trophectoderm. Human Reproduction, Vol. 23, No.8 pp. 1742-1747

Viville, S. Messaddeq, N., Flori, E. and Gerlinger, P. (1998). Preparing for preimplantation genetic diagnosis in France. Hum. Reprod., 13: 10221029. 
Willadsen, S.M. (1979). A method for culture of micromanipulated sheep embryos and its use to produced mono-zygotic twins. Nature, 278: 298-300.

Willadsen, S.M. (1982). Micromanipulation potential of embryos of the large domestic species. In Adms, C.E. (ed) Mammalian Egg Transfer. CRC press, Boca Raton, USA, PP. 185-210.

Willadsen, S. M. (1991). The developmental capacity of blastomeres from 4 and 8 cells sheep Embryos. J. Embryol. Exp. Morphol.; 17: 527-31.

Willadsen, S. M. and Godke, R. A. (1984). A simple procedure for the production of identical sheep twins. Vet. Rec.; 114: 240-243.

Wilton, N.V. and Trounson, A.O. (1999). Biopsy of preimplantation mouse embryo. Development of micro manipulated and proliferation of single blastomeres in vitro. Biol. Reprod.; 40: 145-152.

Wu, G. and Morris, S.M. (1998). Arginine metabolism: nitric oxide and beyond. Biochemical Journal, 336: 1-6.

\section{القدرة التطويرية معمليا للخلايا المعزوله من أجنه الأراتب في مرحلة و وم خلية

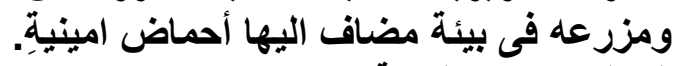 شريف مغاورى شنامية بئة معهز بحوث الإنتاج الحيواني-، مركز البحوث الزراعية الدقي ، الجيزة ، مصر.}

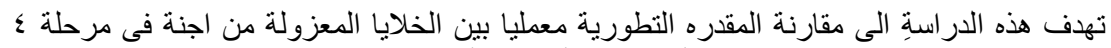

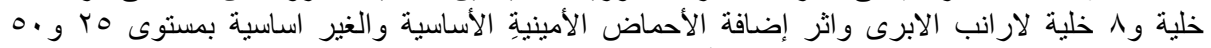

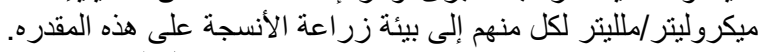

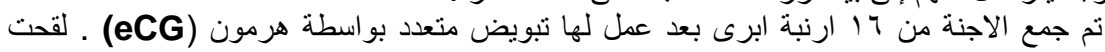

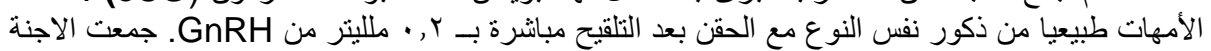

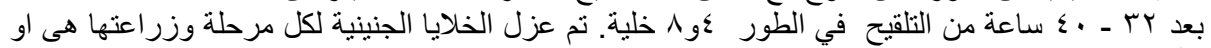

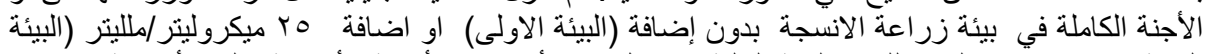

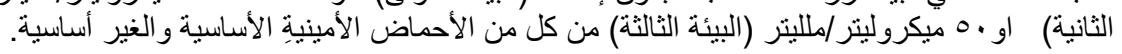
وكانت النتائج المتحصل علئها كالتالي:

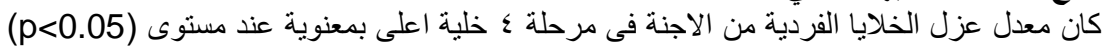

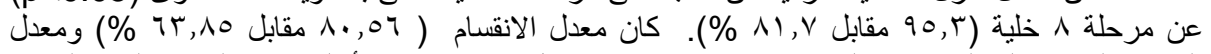

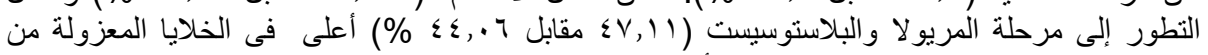
الاجنة فى مرحكة ؛ خلية عن المعزولة من الأجنة فى مرحلة 1 خلية.

كذلك كان معدل الانقسام (

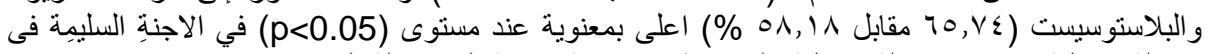

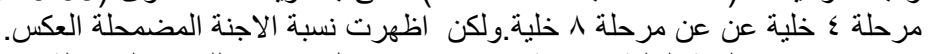

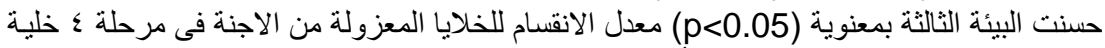

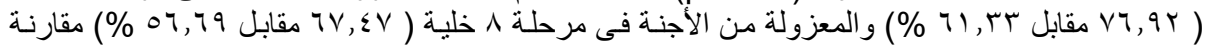

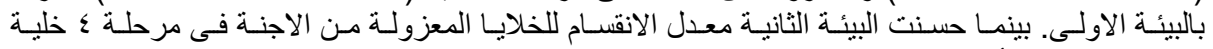

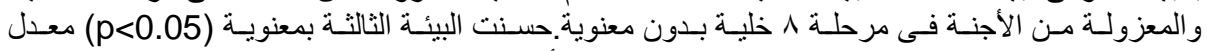

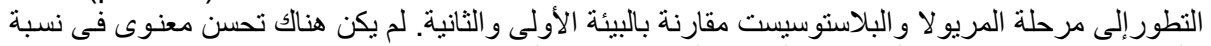

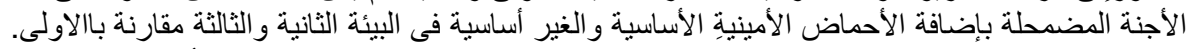

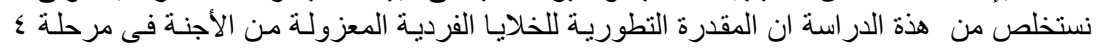

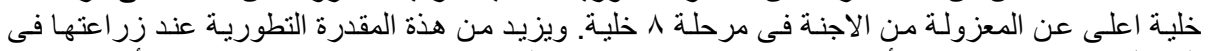

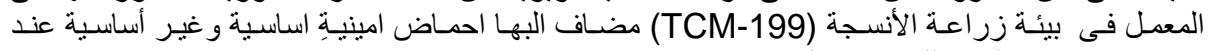
مستوى .0 ميكروليتر /ملليتر من كل منهم. 